\title{
CLIL and Education Coming Together: The Crossroads for Multilingualism
}

\author{
AICLE y la educación se unen: \\ La encrucijada del multilingüismo
}

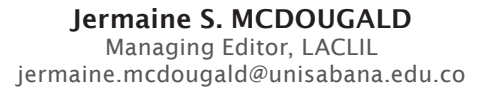

Jermaine S. MCDOUGALD

jermaine.mcdougald@unisabana.edu.co
Carl Edlund ANDERSON

Editor-in-Chief, LACLIL

carl.anderson@unisabana.edu.co

doi: 10.5294/lacli1.2015.8.2.1

It has been only 7 years since both the first issue of the Latin American Journal of Content and Language Integrated Learning (LACLIL) was published and the $1^{\text {st }}$ CLIL Symposium was held at the Universidad de La Sabana in Chía, Colombia in 2008. Over this period, the pace of debate on education and languages has only increased, and growing interest in CLIL (content and language integrated learning) approaches continues to raise new questions for researchers, teachers, policy makers, and learners - indeed, society at large - about the needs for, and challenges of, integrating content and additional (or even first) languages in the classroom and beyond.

During these years, both LACLIL and the CLIL Symposium (now a regular biennial event) have matured and grown in their mission serve as crossroads for contact and communication between CLIL researchers and practitioners in not merely Colombia, but the wider Latin American region - and, indeed, the world. LACLIL has, to date, published more than 74 articles in contribution to the wider story of how language and content teaching has been unfolding throughout Colombia, Latin America, and the world. Contributions have been received from researchers in counties including Argentina, Mexico, the United States of America, Canada, the United Kingdom, the Netherlands, France, Italy, Germany, Poland, Iran, Thailand, South Korea, and Japan. Similarly, the CLIL Symposia have provided spaces in which researchers and-importantly_teachers from Colombia and beyond have come together to share knowledge and ideas, questions 
and answers, to bridge the gap between theory and practice. The $5^{\text {th }}$ Biennial CLIL Symposium, titled New Trends, Challenges, and Opportunities in the CLIL Classroom, held at the Universidad de La Sabana in September, 2014 brought together more than 400 people from different countries and continents, united by their interests in furthering the exploration of educational approaches based around content and language integrated learning (CLIL). Now, with this October 2015 issue, it is possible for LACLIL to help bring some of the work from that Symposium to a wider audience as the present issue of the journal is for the first time published in a traditional, printed format as well as online.

Do Coyle hardly needs introduction to the CLIL community; her work on the development of the 4Cs (content, communication, cognition, and culture) framework, first proposed over 15 years ago (Coyle, 1999), is well-known and often cited. Her paper (Coyle, 2015, this volume) shows how her recent work with the Graz Group continues to seek new and improved ways of integrating aspects represented in the 4Cs through the Pluriliteracies Framework in response to the noted impact of contextual variables on CLIL implementation. Darío Luis Banegas has become an increasingly strong voice for CLIL in recent years. With feet in both the European (Warwick University, UK) and American (Ministry of Education of Chubut, Argentina) spheres, he is well prepared for consideration of the local as well as global issues that go hand-in-hand with CLIL. His paper (Banegas, 2015, this volume), exploring language-driven CLIL models with teachers in Argentina, reminds us that, due in a large part to CLIL's context-driven nature, many areas such as teacher training are constantly changing

As noted, the $5^{\text {th }}$ Biennial CLIL Symposium and LACLIL are both spaces where local and global intersect, as well as where research and teaching practice intersect. Sergio Lozano Velandia is a Colombian teacher-researcher whose paper (Lozano Velandia, 2015, this volume) reports on a study about integrating CLIL approaches into the related, but distinct, context of a language for specific purposes 
(LSP) course at the adult/professional level. The importance of this kind of education is, arguably, extremely important for many adults professional skills and their communicative competences in an additional language simultaneously. His study looked not only at enhancing the interactivity of CLIL-based learning but also the use of self-reflection as a life-long learning strategy. The final paper from the $5^{\text {th }}$ Biennial CLIL Symposium included here, from Carlos Eduardo Aguilar Cortés and Nelson Eduardo Alzate B. (2015, this volume), takes on the important issue of CLIL- and/or CBI-based curriculum design within the context of an existing institution-and important issue for many educators in many contexts around the world. Reporting on the experience their own institution went through, they offer a number of valuable insights on successfully managing (and mediating) the relationships between content teachers and language teachers during such a process.

Even the small selection of papers included here from the $5^{\text {th }}$ Biennial CLIL Symposium should give a sense of how that event (and other CLIL Symposia before it) combines current initiatives in research and practice from both local and global ambits. Although we hope this sense is amplified and extended through the inclusion of several additional papers in this issue of LACLIL submitted by researchers working in various additional countries. Ali Akbar Farahani and Soory Salajegheh (2015, this volume) from Iran address the sometimes controversial issue of when feedback is delivered in the language classroom, comparing the contrasting preferences of students and teachers. Ricardo Casan-Pitarch (2015, this volume), from Spain, is another researcher looking for ways to expand the utility of CLIL approaches by melding them with other pedagogical strategiesin this case, project work. Finally, Khwanchit Suwannoppharat and Sumalee Chinokul (2015, this volume), from Thailand, consider issues and challenges attending the implementation of CLIL in that country. Like many researchers, they note the importance of taking contextspecific local conditions into account, and recognize the importance 
of elements like teacher training and careful planning, cautioning against overly hasty implementations of the kind that have sometime come to grief in other contexts. Such context- or even country-specific studies can be of special interest in CLIL research, and offer relevance that extends far beyond their borders, as little is yet known about the respective experiences and fates of CLIL projects of all sizes beyond some relatively well-represented European contexts. Considering the still novel nature of the CLIL approach as such and the significant distance between it and "traditional" approaches to content learning and, separately, language learning, CLIL researchers in practitioner in almost any context stand to learn from the experiences of their colleagues in other, potentially quite different contexts.

In this sense, and as suggested above, teachers play a pivotal role in connecting educational research and application, theory and practice. CLIL, as noted, is highly context dependent (see, for example, Coyle, Hood, \& Marsh, 2010; Mehisto, Marsh, \& Frigols-Martín, 2008; and Coyle, this volume), and no one has a better view on a specific classroom context than the teacher on the spot. Thus, besides the extensively recognized need for CLIL-oriented teacher training (Aiello, Di Martino, \& Di Sabato, 2015; Banegas, 2012; Biçaku, 2011; Curtis, 2012a, 2012b; Hillyard, 2011; Hunt, Neofitou, \& Redford, 2009; Lucietto, 2009; McDougald, 2015b; Novotná, Hadj-Moussová, \& Hofmannová, 2001; Pistorio, 2009; San Isidro Agrelo, 2009), there is an equally pressing but perhaps less commonly discussed needs to prepare teachers to conduct and publish their own research-though the importance of qualified teacher-researchers to the construction of quality educational systems is not a secret (Sahlberg, 2010, 2014). This, in turn, requires attention to educational policies that not only allow for the implementation of CLIL, which does not fit comfortably into most existing educational paradigms, but that provide for appropriate training for teachers to take up their necessary leading roles most effectively (Biçaku, 2011; Cenoz, 2013; Dalton-Puffer, 2011; Ruiz de Zarobe, 2013). 
This is not to say that teachers are not already driving grassroots efforts in the innovation of pedagogical practices. Teachers know as well as any that an increasingly globalized, multilingual knowledgedriven society requires learners to be able to adapt to contextual demands by identifying the resources and communicative strategies needed to overcome the challenges they will inevitably face. CLIL approaches, inherently oriented towards equipping learners for lifelong learning - and lifelong problem-solving_provide students with opportunities to put their learning into practice. The development of such skills and competences must lie at the heart of any successful $21^{\text {st }}$-century educational program (Coyle et al., 2010; Coyle, 2007; Lorenzo, 2007).

The great variety of possibilities that CLIL offers teachers and learners alike - in terms of innovative methods, forms of interaction, and assessment procedures, and learning objectives - to engage students in active learning through cognitively challenging tasks and authentic, relevant materials help make it an attractive approach for many educational institutions. Thus, in recent years, we have seen CLIL continue to cross yet further borders into new cultural spheres and (despite the relative dominance of English) an expanding array of vehicular languages. LACLIL has published the work of several scholars on teaching content and Spanish through CLIL approaches (Hughes, 2013; Smith, 2015) as well as considering the role of CLIL trilingual educational contexts (González Gándara, 2015; Guillamón \& Renau Renau, 2015). Yet considering the inherently multilingual nature of the Americas - not to mention Europe, Asia, Africa, and Australia - there is considerable scope for more research on CLIL beyond the Anglosphere, including roles that could support minority and endangered languages (though see J. Anderson, 2009; also, a number of individual papers in Lasagabaster \& Ruiz de Zarobe, 2010). CLIL was conceived partially with the intention of connecting globalized thinking to localized action, as teachers around the world shape their classrooms in ways that promote intercultural awareness 
through both "big" and "small" (Holliday, 1999, 2013), national and international cultures. Increasingly, intercultural competence are recognized basic, key skills that need to be embedded in classroom, curricular, and even system-wide planning - as they are already embedded in the CLIL approach.

The phenomena of globalization and the "knowledge age" have fundamentally altered visions of education and what it is meant to achieve. The guiding principles are no longer those of knowledge transmission and consumption but of knowledge creation (Coyle et al., 2010). This requires learners to not only understand information but to construct their own meanings - a capacity dependent on the development of high order thinking skills. Yet though the expectations and challenges - as well as very real risks for the recklesshave increased for teachers and learners alike, the institutionalization of CLIL approaches would represent a decisive first step in moving towards the new approaches to learning that $21^{\text {st }}$-century citizens both need and deserve (C. E. Anderson, McDougald, \& Cuesta Medina, 2015; Banegas, 2015 (this volume); McDougald, 2015a).

Of course, though it may seem a cliché of research communication, it can hardly be denied that "much work remains to be done" with respect to CLIL, not least in areas such pedagogical principles, teacher training, educational and language policy, curriculum and materials development, and assessment. Yet as we have seen —and as the papers in this and past volumes of LACLIL (as well as in the series of CLIL Symposia) show - there is also an expanding CLIL community of researchers and practitioners taking up the challenges. As we move ahead with building a innovative approach to education for a rapidly changing world, the Latin American Journal of Content and Language Integrated Learning looks forward to facilitating the journey as a crossroads for that community. 


\section{REFERENCES}

Aguilar Cortés, C. E. \& Alzate B., N. E. (2015). The dialogues between content and language: Cautions and challenges in the emergence of a bilingual education program. Latin American Journal of Content and Language Integrated Learning, 8(2), 0000. http://dx.doi.org/10.5294/laclil.2015.8.2.5

Aiello, J., Di Martino, E. \& Di Sabato, B. (2015). Preparing teachers in Italy for CLIL: reflections on assessment, language proficiency and willingness to communicate. International Journal of Bilingual Education and Bilingualism, 1-15. http://dx.doi.or $\mathrm{g} / 10.1080 / 13670050.2015 .1041873$

Anderson, C. E., McDougald, J. S. \& Cuesta Medina, L. (2015). CLIL for young learners. In C. N. Giannikas, L. McLaughlin, G. Fanning \& N. Deutsch Muller (Eds.), Children learning English: From research to practice (pp. 137-151). Reading, UK: Garnet. Anderson, J. (2009). Relevance of CLIL in developing pedagogies for minority language teaching. In D. Marsh, P. Mehisto, D. Wolff, R. Aliaga, T. Asikainen, \& M. J. Frigols-Martin (Eds.), CLIL practice: Perspectives from the field (pp. 124-132). Jyväskylä: CCN: University of Jyväskylä.

Banegas, D. L. (2012). CLIL teacher development: Challenges and experiences. Latin American Journal of Content and Language Integrated Learning, 5(1), 46-56. http://dx.doi.org/10.5294/ laclil.2012.5.1.4

Banegas, D. L. (2015). Sharing views of CLIL lesson planning in language teacher education. Latin American Journal of Content and Language Integrated Learning, 8(2),00-00. http: / / dx.doi. org/10.5294/laclil.2015.8.2.3

Biçaku, R. Ç. /. (2011). CLIL and teacher training. Procedia - Social and Behavioral Sciences, 15, 3821-3825. http://dx.doi. org/10.1016/j.sbspro.2011.04.379 
Casan-Pitarch, R. (2015). Project work in CLIL: A bibliographical review. Latin American Journal of Content and Language Integrated Learning, 8(2), 00-00. http://dx.doi.org/10.5294/ laclil.2015.8.2.6

Cenoz, J. (2013). Discussion: Towards an educational perspective in CLIL language policy and pedagogical practice. International Journal of Bilingual Education and Bilingualism, 16(3), 389394. http://dx.doi.org/10.1080/13670050.2013.777392

Coyle, D. (1999). Supporting students in content and language integrated learning contexts: Planning for effective classrooms. In J. Masih (Ed.), Learning through a foreign language: Models, methods and outcomes (pp. 46-62). London, England: CILT Publications.

Coyle, D. (2007). Content and language integrated learning: Towards a connected research agenda for CLIL pedagogies. International Journal of Bilingual Education and Bilingualism, 10(5), 543562. http://dx.doi.org/10.2167/beb459.0

Coyle, D. (2015). Strengthening integrated learning: Towards a new era for pluriliteracies and intercultural learning. Latin American Journal of Content and Language Integrated Learning, 8(2), 00 00. http://dx.doi.org/10.5294/laclil.2015.8.2.2

Coyle, D., Hood, P., \& Marsh, D. (2010). CLIL: Content and language integrated learning. Cambridge, UK: Cambridge University Press.

Curtis, A. (2012a). Colombian teachers' questions about CLIL: Hearing their voices - in spite of "the mess" (Part I). Latin American Journal of Content and Language Integrated Learning, 5(1), 1-8. http://dx.doi.org/10.5294/laclil.2012.5.1.1

Curtis, A. (2012b). Colombian teachers' questions about CLIL: What can teachers' questions tell us? (Part II). Latin American Journal of Content and Language Integrated Learning, 5(2), 1-12. http://dx.doi.org/10.5294/laclil.2012.5.2.6 
Dalton-Puffer, C. (2011). Content-and-language integrated learning: From practice to principles? Annual Review of Applied Linguistics, 31, 182-204. http://dx.doi.org/10.1017/ S0267190511000092

Farahani, A. A. \& Salajegheh, S. (2015). Iranian EFL teachers' and learners' perspectives of oral error correction: Does the timeline of correction matter? Latin American Journal of Content and Language Integrated Learning, 8(2), 00-00. http://dx.doi.org/10.5294/laclil.2015.8.2.6

González Gándara, D. (2015). CLIL in Galicia: Repercussions on academic performance. Latin American Journal of Content and Language Integrated Learning, 8(1), 13-24. http://dx.doi. org/10.5294/laclil.2014.8.1.2

Guillamón, F. \& Renau Renau, M. L. (2015). A critical vision of the CLIL approach in secondary education: A study in the Valencian Community in Spain. Latin American Journal of Content and Language Integrated Learning, 8(2007), 1-12. http://dx.doi.org/10.5294/laclil.2014.8.1.1

Hillyard, S. (2011). First steps in CLIL: Training the teachers. Latin American Journal of Content and Language Integrated Learning, 4(2), 1-12. http://dx.doi.org/10.5294/laclil.2011.4.2.1

Holliday, A. (1999). Small cultures. Applied Linguistics, 20(2), 237264. http://dx.doi.org/10.1093/applin/20.2.237

Holliday, A. (2013). Understanding intercultural communication: Negotiating a grammar of culture. London, UK: Routledge.

Hughes, N. (2013). Developing academic register in CLIL: UKbased Spanish L2 students' Latin America Political Economy writing in the UK. Latin American Journal of Content of Language Integrated Learning, 6(2), 42-71. http://dx.doi. org/10.5294/3149

Hunt, M., Neofitou, A. \& Redford, J. (2009). Developing CLIL training for modern languages teacher trainees. In D. Marsh, P. Mehisto, D. Wolff, R. Aliaga, T. Asikainen, M. J. Frigols- 
Martin, ... G. Langé (Eds.), CLIL practice: Perspectives from the field (pp. 110-116). Jyväskylä, Finland: CLIL Cascade Network, University of Jyväskylä.

Lasagabaster, D. \& Ruiz de Zarobe, Y. (Eds.) (2010). CLIL in Spain:

Implementation, results and teacher training. Newcastle upon

Tyne, UK: Cambridge Scholars Publishing.

Lorenzo, F. (2007). The sociolinguistics of CLIL: Language planning and language change in 21 st century Europe. Revista Española de Lingüística Aplicada, 20, 27-38.

Lozano Velandia, S. A. (2015). Goal-setting and self-reflection to enhance learners' interaction in an ESP context. Latin American Journal of Content and Language Integrated Learning, 8(2), 00-00. http://dx.doi.org/10.5294/laclil.2015.8.2.4

Lucietto, S. (2009). Tateo: A school- and action research-based continuous professional development model for experienced/ senior secondary teachers new to CLIL. In D. Marsh, P. Mehisto, D. Wolff, R. Aliaga, T. Asikainen, M. J. FrigolsMartin, ... G. Langé (Eds.), CLIL practice: Perspectives from the field (pp. 117-124). Jyväskylä: CCN: University of Jyväskylä. McDougald, J. S. (2015a). AICLE: un nuevo enfoque para el aprendizaje bilingüe/CLIL: A fresh approach to bilingual learning. Ruta Maestra, 11, 30-38.

McDougald, J. S. (2015b). Teachers' attitudes, perceptions and experiences in CLIL: A look at content and language. Colombian Applied Linguistics Journal, 17(1), 25. http:// dx.doi.org/10.14483/udistrital.jour.calj.2015.1.a02

Mehisto, P., Marsh, D. \& Frigols-Martín, M. J. (2008). Uncovering CLIL: Content and language integrated learning in bilingual and multilingual education. Oxford, UK: Macmillan Education.

Novotná, J., Hadj-Moussová, Z. \& Hofmannová, M. (2001). Teacher training for CLIL: Competences of a CLIL teacher. In M. Hejný \& J. Novotná (Eds.), Proceedings SEMT 01 (pp. 122126). Prague: Univerzita Karlova v Praze, Pedagogická fakulta. 
Pistorio, M. I. (2009). Teacher training and competences for effective CLIL teaching in Argentina. Latin American Journal of Content and Language Integrated Learning, 2(2), 37-43.

Ruiz de Zarobe, Y. (2013). CLIL implementation: From policy-makers to individual initiatives. International Journal of Bilingual Education and Bilingualism, 16(3), 231-243. http://dx.doi. org/10.1080/13670050.2013.777383

Sahlberg, P. (2010). The secret to Finland's success: Educating teachers. Stanford, CA: Stanford Center for Opportunity Policy in Education.

Sahlberg, P. (2014). Finnish lessons 2.0: What can the world learn from educational change in Finland? (2nd ed.). New York, NY: Teachers College Press.

San Isidro Agrelo, X. (2009). CLIL, un nuevo horizonte en la formación del profesorado. Latin American Journal of Content and Language Integrated Learning, 2(1), 51-54.

Smith, B. (2015). La ansiedad y la presencia de un desconocido en una clase de lenguas extranjeras. Latin American Journal of Content and Language Integrated Learning, 8(1), 36-42. http://dx.doi. org/10.5294/laclil.2014.8.1.4

Suwannoppharat, K. \& Chinokul, S. (2015). Applying CLIL to English language teaching in Thailand: Issues and challenges. Latin American Journal of Content and Language Integrated Learning, 8(2), 00-00. http://dx.doi.org/10.5294/laclil.2015.8.2.7 